\title{
Sternal and vertebral fractures, a well-known association, usually overlooked: review of six clinical cases
}

\author{
Fraturas vertebrais e fraturas concomitantes do esterno: \\ revisão de seis casos
}

\author{
Fracturas vertebrales y fracturas concomitantes del esternón: \\ revisión de seis casos
}

\author{
Alvaro Silva G. ${ }^{1,2}$ \\ Paulina de la Fuente D. ${ }^{2}$ \\ Andrés Schmidt-Hebbel N. ${ }^{3}$ \\ Manuel Valencia C. ${ }^{1,2}$ \\ José Antonio Riera M. ${ }^{1,2}$ \\ Javier del Río A. ${ }^{1,2}$ \\ Bernardo Merello T. ${ }^{1,2}$ \\ Carlos Thibaut L. ${ }^{1,2}$
}

\begin{abstract}
Objective: the association of sternal and vertebral fractures has previously been described in the literature. These lesions are frequently overlooked at the initial evaluation. The purpose of this study was to review and discuss the diagnostic methods used to diagnose these lesions and to highlight the importance of early recognition of these fractures. Methods: we performed a retrospective analysis of six patients who suffered sternal and concomitant vertebral fractures. Clinical charts and imaging studies were reviewed. Results: all patients were diagnosed with sternal fractures at the initial evaluation, but only two were diagnosed with vertebral fractures. Conclusion: failure to recognize these fractures at initial evaluation may be associated with the
\end{abstract}

\section{RESUMO}

Objetivo: a associação de fraturas do esterno e vertebral tem sido previamente descrita na literatura. Essas lesões são frequentemente negligenciadas na avaliação inicial. O objetivo deste estudo foi analisar e discutir os métodos diagnósticos utilizados para essas lesões e salientar a importância do reconhecimento precoce dessas fraturas. Métodos: foi realizada uma análise retrospectiva de seis pacientes que sofreram, concomitantemente, fraturas do esterno e vertebrais, por meio da análise de prontuários e exames de imagem. Resultados: todos os pacientes foram diagnosticados com fraturas do esterno na avaliação inicial, mas somente dois foram diagnosticados com fraturas vertebrais. Conclusão: o não-reconhecimento dessas fraturas na avaliação inicial

\section{RESUMEN}

Objetivo: la asociación de las fracturas del esternón y vertebrales ha sido descrita previamente en la literatura. Estas lesiones son frecuentemente descuidadas en la evaluación inicial. El objetivo de este estudio fue analizar y discutir los métodos diagnósticos utilizados para estas lesiones y resaltar la importancia del reconocimiento precoz de estas fracturas. Métodos: fue realizado un análisis retrospectivo de seis pacientes que sufrieron concomitantemente fracturas del esternón y vertebrales, por medio del análisis de las historias clínicas y exámenes de imagen. Resultados: todos los pacientes fueron diagnosticados con fracturas del esternón en la evaluación inicial, pero solamente dos fueron diagnosticados con fracturas vertebrales. Conclusio-

\footnotetext{
Study carried out at Departament of Orthopaedics and Traumatology Clínica Alemana de Santiago, Universidad del Desarrollo - Santiago, Chile.

'MD, Hospital Mutual de Seguridad de Santiago - Santiago, Chile.

${ }^{2} \mathrm{MD}$, Departament of Orthopaedics and Traumatology, Clínica Alemana de Santiago, Universidad del Desarrollo - Santiago, Chile.

${ }^{3} \mathrm{MD}$, Facultad de Medicina Clínica Alemana de Santiago, Universidad del Desarrollo - Santiago, Chile.

The authors did not have sources of support 
fact that the upper thoracic region is difficult to explore. In the presence of sternal fractures, a vertebral fracture must be ruled out even though major injuries are not present. A computer tomography (CT) scan and magnetic resonance imaging (MRI) should be obtained despite negative $X$-rays if clinical suspicion is present. pode ser associado à dificuldade de explorar a região torácica superior. Na presença de fraturas do esterno, uma fratura vertebral deve ser descartada, embora lesões maiores não sejam presentes. A tomografia computadorizada (TC) e a ressonância magnética (RM) devem ser obtidas se houver suspeita clínica, apesar de os raios-X serem negativos.

DESCRITORES: Esterno/lesões; Fraturas da coluna vertebral nes: el hecho de no reconocer estas fracturas en la evaluación inicial puede estar asociado a la dificultad de explorar la región torácica superior. En la presencia de fracturas del esternón, una fractura vertebral debe ser descartada, así no estén presentes lesiones mayores. La tomografía computarizada y la resonancia magnética deben ser obtenidas en el momento de sospecha clínica, aunque el rayo-X sea negativo.

DESCRIPTORES: Esternón/ lesiones; Fracturas de la columna vertebral

\section{INTRODUCTION}

Sternal fractures in combination with vertebral fractures have been traditionally described as associated injuries ${ }^{1,2}$. Their incidence remains uncertain and probably underestimated ${ }^{3,4}$

These injuries may result in devastating consequences because of high levels of neurological compromise and severe concomitant injuries ${ }^{1}$.

The stability of the upper thoracic spine is supplemented by the sternum and rib cage ${ }^{5}$, thus the combination of these two fractures may result in severe instability of the spine $^{4}$. For this reason, failure to recognize these lesions at initial work-up may lead to chronic pain and progressive kyphotic deformity ${ }^{1,6}$.

In this paper we reviewed a series of patients who suffered a sternum fracture in combination with vertebral fractures, along with analyzing and discussing the diagnostic algorithms used to identify these fractures.

\section{METHODS}

From January 2007 to December 2008, six patients with sternal and vertebral fractures were admitted to our unit. We have retrospectively analyzed their clinical charts and imaging studies to determine the way these injuries were diagnosed.

The patients were all male, with a mean age of 49 years. Three of them were injured in falls from height, two were struck by heavy objects from the back and one was involved in a road traffic accident.

\section{RESULTS}

At the initial evaluation, all six patients were diagnosed with a sternal fracture (mostly affecting the body of the sternum), but only two of them were diagnosed with concomitant vertebral fractures noticed on a computed tomography (CT) imaging study (Figure 1).
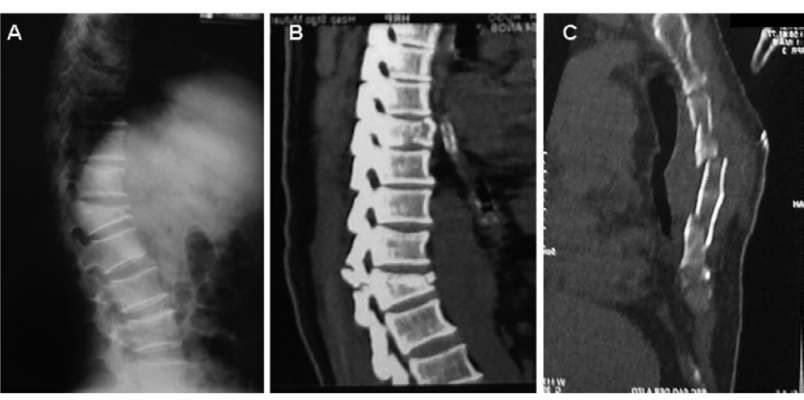

Figure 1

Lateral spine radiograph (A) and CT-scan (B) showing a Burst fracture at T8 level and wedge fractures at T1 1-T12; CT scan showing comminuted sternal body fracture (C).

These two patients also had associated major trauma (pulmonary contusion, hemopneumothorax, cranioencephalic trauma) and spinal cord injury, one at T6 and the other at T3-T4 level, requiring spinal surgery.

The four remaining patients all had initial X-rays that did not reveal vertebral fractures, but eventually all of them evolved with pain during physical examination, which increased our suspicion of unnoticed vertebral fractures.

In three of these patients, vertebral fractures were confirmed with a CT scan, and in one patient with negative CT scan, a magnetic resonance imaging (MRI) showed vertebral fracture edema in T12 and L1 (Figures 2A, 2B, 2C).

In the other patients, fractures were present from $\mathrm{T} 3$ to L1, and all except one patient had multilevel fractures.

These patients were treated orthopedically and they all progressed favorably.

\section{DISCUSSION}

Assessment of patients with spinal or thoracic trauma requires an awareness of different associated injury patterns ${ }^{4}$. The combination of sternal and vertebral fractures ${ }^{4}$ remains a challenge for clinicians because of its rareness, 


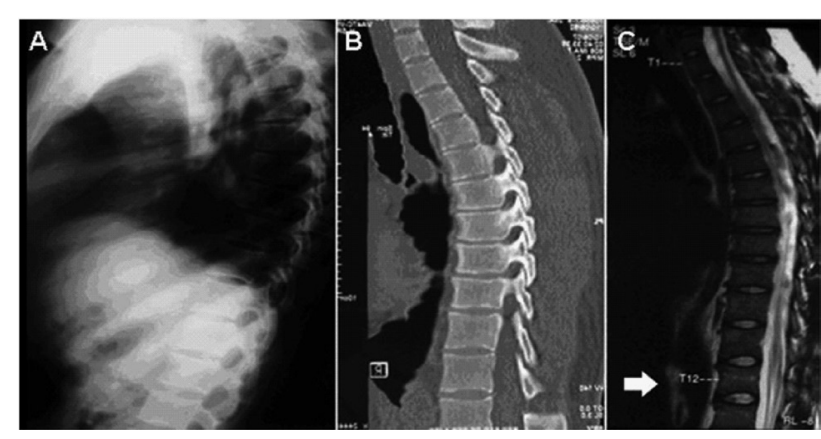

Figure 2

Lateral spine radiograph (A) and CT scan (B) where spine fracture is not clearly evidenced; Spine MRI showing vertebral edema at T12 level (C).

and is easily overlooked in patients with multiple injuries. This may be due to the fact that the upper thoracic region is difficult to explore on standard chest and spinal radiographs ${ }^{1}$ and/or that many of these lesions are not suspected or not given much importance as isolated fractures of the sternum are mostly benign ${ }^{7,8}$ and may not require special treatment. Nevertheless, it is important to consider that enormous forces are needed to result in this type of lesions, thus making it necessary to rule out any other concomitant injuries such as spinal cord injury, hemopneumothorax, heart or pulmonary contusion ${ }^{1,4,9}$. Therefore, in order to exclude associated injuries, careful clinical examination is important while approaching a patient with an alleged isolated sternal fracture ${ }^{7}$.

The severity of displacement of a sternal fracture has been suggested by some authors as a useful marker of associated injury. A severely displaced sternal fracture may also serve as an indicator of potentially serious cardiac injury?

Since specific radiographic examination of the sternum is not a routine part of blunt trauma assessment, a careful examination should be performed in critically injured patients who cannot complain of chest pain ${ }^{10}$. In these situations, occult sternal fractures may remain undiagnosed because more severe injuries command the focus of evaluation ${ }^{10}$.

As sternal fracture displacements occur in the sagittal plane, lateral radiographs are the most useful images in identifying and determining the degree of injury. A lateral radiograph of the sternum would, therefore, be recommended to screen for suspected sternal injury in patients with spinal injury ${ }^{10}$.

As mentioned above, thoracic spine differs from other regions because of the stability provided by the sternum and rib cage ${ }^{5,11}$. They restrict movement and increase spine rigidity, thereby adding a veritable fourth column and an essential mechanical support ${ }^{12}$. This fourth column supplements the three-column model of spinal stability described by Denis ${ }^{1}$.

Watkins et al. ${ }^{11}$ estimated that a sternal fracture decreased the stability of the thoracic spine by $42 \%$ in flexion/ extension, $22 \%$ in lateral bending and $15 \%$ in axial rotation.
Therefore, fractures of the sternum may decrease stability making a thoracic spine fracture unstable ${ }^{1,4,11}$. This is the reason why it is so important to identify these lesions, as they behave in a different way when associated.

Remarkably, sternal fractures were easily diagnosed at the initial evaluation in our series, probably because of the routine thorax exploration in patients with multiple trauma, unlike vertebral fractures that were missed in 4 patients $(66,6 \%)$ even though they were initially suspected, but ruled out without further exploration as X-rays were negative.

Fractures diagnosed at initial work-up were present in patients who had associated major trauma and neurologic involvement, and therefore required further examination.

These injuries were easily overlooked in the patients bearing minor trauma, which is why it is essential to suspect vertebral fractures in the presence of a sternal fracture even though major injuries and neurologic compromise are not present.

The presence of spinal-palpation pain in subsequent assessments was the sign that lead us to suspect the presence of vertebral fractures. Even though a CT scan confirmed the fractures in three of the patients, one patient had persistent pain, which required an MRI to confirm the occult vertebral fracture.

The explanation for not detecting the fracture at the initial work-up is not stated on the clinical charts, but it could have been due to lack of physical examination or non-evaluable radiology.

A CT scan and MRI may be necessary to rule out a fracture when spinal pain persists. The CT scan must show both sternal and vertebral fractures on the same sagittal reconstruction plane as the image is often directed only at the spinal injury and must encompass the whole spine in order to avoid overlooking other fractures ${ }^{4}$.

Regarding treatment of these lesions, it has been found that surgical fixation of sternal fractures is generally unnecessary when posterior spinal reduction and stabilization is performed ${ }^{1,4}$.

Even though many authors treated most of the spine fractures with posterior stabilization ${ }^{1,4,6}$, (as they are considered unstable lesions $)^{1,4,11}$, in our series most of our patients were managed conservatively with close supervision and good outcomes. Only two patients underwent surgery, both with spinal cord injury and one with a burst fracture.

\section{CONCLUSION}

Sternal fractures are often overlooked as they are not suspected at the initial work-up, hence a high index of suspicion is required to detect these lesions.

We recommend that whenever confronting a sternal fracture, a vertebral involvement must be suspected even though major injuries may not be present. Clinical suspicion of a fracture arising from persistent spinal-palpation pain must be ruled out with a CT scan or MRI despite negative $\mathrm{X}$-rays, when deemed appropriate. 


\section{REFERÊNCIAS}

1. Labbe JL, Peres O, Leclair O, Goulon R, Scemama P, Jourdel F. Fractures of the upper transthoracic cage. J Bone Joint Surg Br. 2009;91(1):91-6.

2. Lund J, Chojnowski A, Crawford R. Multiple thoracic spine wedge fractures with associated sternal fracture; an unstable combination. Injury. 2001;32(3):254-5.

3. Gopalakrishnan KC, el Masri WS. Fractures of the sternum associated with spinal injury. J Bone Joint Surg Br. 1986;68(2):178-81.

4. Vioreanu MH, Quinlan JF, Robertson I, O'Byrne JM. Vertebral fractures and concomitant fractures of the sternum. Int Orthop. 2005;29(6): 339-42.

5. Adamo MA, Deshaies EM, German JW, Popp AJ, Dirisio DA. Management of thoracic spine injuries: Part I: Thoracic spine anatomy and stability. Contemp Neurosurg. 2006;28(20):1-5.
6. Klaase JM, Zimmerman KW, Veldhuis EF. Increased kyphosis by a combination of fractures of the sternum and thoracic spine. Eur Spine J. 1998;7(1):69-71.

7. Hossain M, Ramavath A, Kulangara J, Andrew JG. Current management of isolated sternal fractures in the UK: time for evidence based practice? A cross-sectional survey and review of literature. Injury. 2010;41(5):495-8.

8. Potaris K, Gakidis J, Mihos P, Voutsinas V, Deligeorgis A, Petsinis V. Management of sternal fractures: 239 cases. Asian Cardiovasc Thorac Ann. 2002;10(2):145-9.

9. Boris K, Itamar A, Elad M, Risin E.Khashan T, Alfici R. Sternal fracture should prompt the evaluation of the entire spine in trauma patients. Eur J Trauma. 2005;31(1):57-60.

10.Chiu W, D'Amelio L, Hammond JS. Sternal fractures in blunt chest trauma: a practical algorithm for management. Am J Emerg Med. 1997;15(3):252-5.
11. Watkins R 4th, Watkins R 3rd, Williams L, Ahlbrand S, Garcia R, Karamanian A, et al. Stability provided by the sternum and rib cage in the thoracic spine. Spine (Phila Pa 1976). 2005;30(11):1283-6.

12. Von Garrel T, Ince A, Junge A, Schnabel M, Bahrs C. The sternal fracture: radiographic analysis of 200 fractures with special reference to concomitant injuries. J Trauma. 2004;57(4):837-44.

\section{Correspondence}

Andrés Schmidt-Hebbel N.

Facultad de Medicina Clínica Alemana Universidad del Desarrollo

Avenida Las Condes 12.438

Lo Barnechea

Santiago, Chile

Tel: +562 2999110

E-mail: andysh@gmail.com 